\title{
Carers, families, relatives: Socio-legal conceptions of care-giving relationships
}

\section{Julia Twigg}

To cite this article: Julia Twigg (1994) Carers, families, relatives: Socio-legal conceptions of care-giving relationships, The Journal of Social Welfare \& Family Law, 16:3, 279-298, DOI: 10.1080/09649069408413613

To link to this article: https://doi.org/10.1080/09649069408413613

册 Published online: 01 Feb 2008.

Submit your article to this journal

Џ Article views: 74

4 Citing articles: 6 View citing articles 진 


\title{
Carers, Families, Relatives: Socio-legal Conceptions of Care- giving Relationships
}

\author{
by Julia Twigg
}

Senior Lecturer, University of Hull

\begin{abstract}
In 1990 for the first time the term "carer" was employed in legislation in the NHS and Community Care Act. The word had emerged in academic literature in the 1970s, spreading to professional discourse in the 1980s; and it marks a change in emphasis from earlier usage in terms of families, relatives and next of kin. The law had previously touched on the areas of care-giving and family relations but within different frames of reference. This paper explores four of these: the "liable relatives" tradition of the Poor Law; the inheritance laws; medical decision-making by next of kin; and the role of the "nearest relative" in mental health legislation. It then discusses the significance of the emergence of the new terminology and the welfare debates within which it is embedded.
\end{abstract}

\section{Introduction}

In 1990 for the first time the word "carer" was employed in statute when the NHS and Community Care Act 1990 laid an obligation on local authorities to consult not only District Health Authorities, Family Health Service Authorities, and agencies in the voluntary sector but also

"the interests of private carers who within that area provide care to persons for whom in the exercise of their social services functions, the local authority have a power or a duty to provide services."

The Act defines "private carer" as "a person who is not employed to provide the care in question," but takes the definition no further (NHS and Community Care Act 1990, section 46). In the extensive government guidance issued in the wake of the Act carers feature more prominently, and the phrase "users and carers" is employed repeatedly, though without explication of the term.

The use of the word marks a new departure in the law's conceptualisation of family relationships and responsibilities. In the second half of this paper I will discuss the implications of the new term: its meaning and the welfare debates within which it is embedded. Before doing so I will explore some of the other ways in which the law has attempted to define or codify family or care-giving relations, exploring four areas: the "liable relatives" tradition of the Poor Law; the inheritance laws; medical decision-making by next of kin; 
and the role of the "nearest relative" in mental health legislation. Each of these touches on aspects of care and caring, though in ways that are significantly different from a conceptualisation in terms of a "carer." The difference between the terms and the significance of the shift in terminology will be explored in the second part of the paper.

\section{"Liable relatives" under the Poor Law}

There is no general obligation under English law for individuals to support their relatives, with the exception of the obligations of parents for their under-age children and of spouses. Established texts on family law such as Hoggett and Pearl (1991) or Eekelaar (1984) touch on the subject only briefly: from the current legal point of view the subject of wider family relations has no status and there is no body of law to discuss. This is in contrast to other European legal traditions, such as that of Germany where the obligation to support relatives has been formally codified. In Germany adult children are required to provide financial support to their parents and can be charged by the public authorities for the cost of both their financial upkeep and care. Similar principles apply in Italy and France (Rheinstein, 1960).

The only area of English law where offspring have been in a comparable position was under the Poor Law which encoded a responsibility for relatives to support their kin in certain circumstances, and provided a means whereby the costs of the public support of individuals could be recouped from their relatives. The Poor Law was formally abolished in 1948. At that point it was not replaced by any other legal definition of family obligation, and English welfare legislation currently imposes no duty on individuals to support their relatives (Finch, 1989).

The shift from an encoded obligation under the Poor Law to none has often been interpreted as supporting the view that "in the past" older and disabled people were cared for by their relatives, and that this was the accepted norm, enforced by the public authorities. The shift to "modern" (or in different versions "industrial" or "capitalist") society and the associated "rise of the welfare state" is seen as effecting a fundamental shift in responsibilities whereby the support of older and disabled people moves away from the sphere of the family and into that of the state. This unilinear and Whiggish account of the transfer of responsibility has been subject to criticism in terms of its analysis both of the present and of the past. Research undertaken in the 1980 s clearly established the primary role still played by the family in the support of disabled and older people (Finch and Groves, 1983; Green, 1988; Arber, et al., 1988). It is not the case that families no longer care for their kin, as has sometimes been asserted by politicians and public moralists (Qureshi and Walker, 1989).

The traditional account has been subject to challenge and emendation from the historical point of view also (Thomson, 1986, 1991; Smith, 1984. Current scholarship emphasises the limited obligations imposed in the past 
by the law in England and the relative lack of assumption that the support of older and disabled people should rightly fall on their kin. Thomson argues that the obligations imposed by the Poor Law were not as great as might appear, and that we need to understand the English tradition as always being one in which the assumption of support by family was only weakly held. From the early modern period onwards, he argues, there was a clear acceptance that the support of indigent older people was something that could be expected to fall on the parish or the collectivity. He points in support of this to the limited range of family obligations imposed by the Poor Law. In relation to older people it extended only to adult children, not to siblings, nieces or nephews, or grandchildren. It did not extend to relationsin-law; and a woman's responsibility for her parents ended at marriage. Grandchildren brought up by grandparents were not obliged to support them. The obligation related only to financial support; and there was no attempt to force relatives to provide other forms of care or to take the elderly person into their homes. The rules applied only where the person was destitute; there was no obligation to give money where the relative was merely poor or where there was a great disparity between the material circumstances of children and their parents. Lastly the obligation to maintain was subject to having sufficient means, and in assessing this the officers of the Poor Law took into account what was recognised as prior responsibilities to support wives and children. Prosecutions in relation to the support of older people were rare, and pursued by the authorities only with reluctance. Thomson concludes that magistrates did not really expect the children of the poor to support their parents. The real thrust of the Poor Law was always against neglectful husbands and fathers, and it was broadly accepted that destitute older people would primarily be supported by the collectivity.

A shift occurred in the policy debate in the late nineteenth century when attempts were made under pressure from what Smith terms "demographically induced difficulties" to "cajole children under legal threat to care for or contribute to the cost of care for their parents" (Smith, 1984, p. 423), but these were unsuccessful and unpopular and ushered in a reaction. The Pensions Act 1908 endowed older people with a degree of financial independence that obviated much of the need to call on relatives for support, and he suggests that this new independence produced better and closer relations between the generations rather than marking a decline in association. The early twentieth-century reformers who created the welfare state formed their perception of the past in relation to this policy debate and to the relatively harsh regime of the late nineteenth century; and the contrast between this and their aspirations was an important source of the image of the past as an age of unquestioned and publicly enforced family obligation (Thomson, 1986).

Thomson argues that if we think of welfare provision as existing between two poles, that of collective responsibility and that of individual (or familial) responsibility, older people have for the last two centuries at least been 
predominantly placed near the collective pole. He, together with Smith (1984), roots this assumption of collective responsibility in the particular demographic regime characteristic of North-West Europe. This is marked by low fertility, late marriage, individual freedom of choice in marriage and relatively low mortality. It is a regime of high mobility, with children leaving the parental home before marriage to enter another household, and of weak links between kin. Marriage, which typically occurs late and depends on access to resources, results in the formation of a new household. Households rarely extend beyond the nuclear family. This pattern which has been characteristic of North-West Europe at least from the late middle ages contrasts with that of, for example, South-East Asia or southern European regimes in the past where marriage has been early, and fertility and mortality high, and where the extended family imposes multiple kinship obligations. Thomson, in line with Laslett $(1972,1977)$ and Smith (1984), argues that the North-West demographic regime imposes considerable risk on individuals. Weak family ties, high mobility, small numbers of offspring and high levels of non-marriage together produce circumstances where many individuals will not be able to call on support from kin. So that although, it is argued, it is a regime that favours the accumulation of savings, their investment in enterprise and thus the crucial break into self-sufficient growth that is the basis of the emergence of capitalism, it is a regime that imposes high risk on individuals. It needs a corresponding commitment by the collectivity to underwrite the security of individuals. The early acceptance of public responsibility for indigent older people in England can therefore be seen in terms of the particular dynamics of its demographic regime, and the liable relatives tradition of the Poor Law placed in that context.

\section{Inheritance laws}

The Poor Law was designed for the regulation of a particular class of people-the poor-and its codification of family obligation was limited to that group. By contrast, the main preoccupation of the law in relation to the family, as Crowther comments, has always been elsewhere, concerned with issues of inheritance (Crowther, 1982). Here the dominant English tradition is not one of obligation but of testamentary freedom.

Testamentary freedom emerged out of earlier medieval restriction during the eighteenth and nineteenth centuries. The process reached its apogee in 1891 , and between then and 1938, testamentary freedom was absolute in England (Oughton and Tyler, 1984). Individuals were free to leave their property as they wished and with no regard to any obligations that they might have to their families. This is in contrast to many Continental traditions, particularly those based on the Napoleonic Code in which certain classes of heirs are given entrenched rights and limits are placed on the proportion of the estate that can be left away from the family. In France, for example, the proportion of the estate with which the testator can deal freely (quotité 
disponible) is a third if he/she has two children and a quarter if he/she has three or more. Similar rules apply in Italy (Dyson, 1987; Hudson and Barbalich, 1991).

English law was modified in 1938 after pressure during the 1920 s and 1930 s from feminists and others concerned with the fate of wives and children left dispossessed. The Inheritance (Family Provision) Act 1938 introduced judicial discretion rather than entrenched rights, and under it the courts were given the power to make reasonable provision for dependent family members notwithstanding the inheritance laws and the principle of freedom of testation. Spouses, under-age sons, unmarried daughters and adult sons and daughters who had mental or physical disabilities could apply for provision. Further adjustments were made in 1966 and 1975 which extended legitimate applicants to include anyone dependent on the deceased. Fixed shares were discussed in the 1970 s but rejected by the Law Commission Report (Oughton and Tyler, 1984).

In none of these formulations are caring and inheritance linked in any legally defined way. The debates that took place in the run-up to the reforms of 1938 and 1975 were concerned not with intergenerational reciprocity in the sense of caring, but with issues of vulnerability and just deserts in relation to wives and children. There had been an earlier tradition that had linked the two in "care contracts" whereby property, usually a farm, was passed to the next generation in return for an explicit undertaking to maintain the older person. Such contracts, however, need to be understood in the context of farms as economic units. As Sorensen concludes: "retirement contracts created in former times should be seen as mechanisms for securing the match between certain families and a property rather than as the manner for providing care for the old" (Sorensen, 1989, p. 211).

During the 1980s, however, caring and inheritance were increasingly linked within policy debates concerning the support of older people. The spread of home ownership held out the promise of a society where an increased proportion of the population would inherit substantial sums; and this occurred in conjunction with a growing perception of housing as a capital asset rather than simply a place to live. Older people were encouraged to see the release of housing equity as a means of funding care (Oldman, 1991). These shifts in perception concerning housing occurred in the context of increasing anxieties as to the public costs of supporting older people and a new right-wing emphasis on individual market solutions. As a result a muted debate emerged in government and policy circles as to whether the costs of caring-emotional and financial-might not be discounted against future inheritance and the problems posed to government by an increasingly articulate carer lobby circumvented in this way. After all, if families were going to inherit the house, perhaps their current activities were not so unreasonably burdensome. 


\section{The involvement of next of kin in decision-making}

It has been common practice in hospitals where the patient is not mentally competent-typically older mentally infirm people-for relatives to be asked to sign giving their consent to major interventions such as surgery. Such requests are related more to a concern to pre-empt a basis for complaint and to gain the agreement of relatives than to legal reality, for relatives or next of kin, as we shall see, are not able in law to give such consent. The process, however, is presented as a legal action and relatives are asked to sign in their capacity as "next of kin," which is how hospitals have traditionally recorded family relationships. The term has a quasi-legal ring to it and some of its roots relate to the duties of the next of kin concerning the registration of death and the arrangements for the disposal of the body. More recently there has been a shift in some hospitals towards employing the term "carer," usually as part of a more systematic approach to discharge planning where the importance of the carer is recognised. As we shall see, the principal carer is frequently the next of kin, though not always, and the two terms have slightly different emphases.

Despite the established practice of consultation, relatives in fact have no legal status in medical decision-making and this extends to spouses. Although it is customary, for example, to gain a spouse's signature on a request for sterilisation, it is not necessary; and women are similarly free to obtain abortions regardless of the wishes of their husbands (Gunn, 1987; Kennedy, 1988). The fact that these decisions could be said to affect the spouses closely does not translate into any right in law to be consulted. This point is important in the context of our understanding of the term "carer," for some at least of the basis for the incorporation of carers into public policy arises from the fact that caring has consequences for their lives and can as a result be said to endow them with a legitimate interest in decision-making. We shall return to this point below.

Where the patient is under age, particularly under the age of 16 (see Family Law Reform Act 1969, section 8), parents do have a capacity to take decisions, including those relating to medical interventions. The extent and basis of their power, however, have been open to dispute, as was illustrated in the Gillick case (Kennedy, 1988). The circumstances of the Gillick case presume an eventual end to parental authority and an assumption of capacity by the child. Where the child has learning disability, however, the situation is more problematic. The gradual assumption of capacity cannot be assumed and, as we shall see, there is no source of valid legal consent to treatment in the case of adults who are mentally incapable, though during their childhood parents are legally capable of taking such decisions as part of a general capacity of parents to do so. This has given rise to the situation where parents have been able to authorise interventions such as abortions and sterilisations while a young woman is under age, but not thereafter. In the past many such operations took place, and not only on those who were under age, and it is only recently that the capacity of parents to act in this way has been challenged. 
The third area where the role of parents in decision-making has been subject to challenge concerns the fate of babies born with severe disabilities. The area is an increasingly contentious one in which doctors have traditionally exercised discretion (Kennedy, 1981). In doing so it has been customary for them to assess the wishes or views of parents, partly to weigh up the likely future of the child, and partly from an idea that parents have a right to a say in the care of their baby. From the legal point of view, neither of these bases is entirely satisfactory. In the recent case of $\operatorname{Re} B$, the Court of Appeal overturned the view of the judge of first instance who had concurred with the decision not to treat the baby, arguing that the judge had put too great an emphasis on the wishes of the parents (Kennedy, 1988). Kennedy supports such a view, asserting that it had never been part of morality or law that parents should have discretion as to whether a child lives or dies.

The situation in regard to adults is different. As we have seen, relatives ordinarily have no rights to be consulted in medical decision-making. Issues arise, however, where the patient is mentally incapable; for example, by reason of severe mental illness, learning disability, or organic brain damage through senile dementia or a stroke. Often in such cases the individual is cared for by a relative, who perforce has to make decisions for them on a dayto-day basis. The legal basis for such decision-making is, however, far from certain. Without valid consent, medical interventions constitute an assault. Where an adult is mentally incapable of giving consent, there is no clear alternative source. The doctrine of necessity covers emergency interventions by a doctor, but not those like routine dental treatment or cervical smears that are merely advisory (Gunn, 1987; Law Commission, 1991). The consent of a relative "is of no effect since there is no power vested in a relative to consent to the treatment of another" (Kennedy, 1988, p. 340). Machinery does exist whereby decisions can be made in regard to property, but this does not extend to decisions concerning the person. Thus the remit of the Court of Protection, deriving from the prerogative powers of the Crown in regard to feudal estates, does not extend to medical decisions. Enduring Power of Attorney, developed in the 1980 s to allow for the continuing management of the affairs of someone who is no longer mentally capable, again cannot extend to medical or personal care decisions, and can only be activated where the person was formerly mentally capable. It cannot cover the circumstances of adults with learning disabilities, nor those who have not made provision in advance.

The area has recently been subject to debate and review in reports by the Law Commission and the Law Society (Law Society, 1989; Law Commission, 1991) and various solutions to the impasse are presented in the Law Commission report. Most are institutionally based; for example, extending the powers of the Court of Protection to cover medical and personal decisions. One, however, rests on establishing a mechanism akin to the intestacy laws whereby prescribed relatives would be endowed with the capacity to make decisions on behalf of a mentally incapable relative. The reasons given for involving relatives in this way are threefold. Throughout the report 
and in the wider debate concerning mental incapacity, preference is given to decision-making based on "substitute judgement" rather than generalised "best interests": and relatives are clearly the most important source of such information as to the putative preferences of the individual. Relatives are also assumed to have the well-being of the patient at heart, though the report recognises that they can act in bad faith. Lastly relatives are already involved: in practice they are the ones making many decisions. Reforms that give them a recognised status would enable this reality of responsibility to be placed on a more satisfactory legal basis. The report proposes as a basis a combination of care-giving responsibility and kinship relation, and points to the mental health legislation where, as we shall see, the law has gone some of the way towards defining such a hierarchy of responsibility among kin.

\section{The "nearest relative" in mental health legislation}

Mental health is the one field of social care where relatives have been endowed with formal powers defined in statute. The Mental Health Act 1983 recognises and gives powers to the "nearest relative" of the patient. These powers centre on the right to make application for compulsory admission of the patient (temporary or long-term) and the right to seek their release. The powers are only those of initiation and request; admission must be supported by two doctors and discharge subject to the approval of the Responsible Medical Officer. The capacity of the "nearest relative" to seek an admission is shared by the Approved Social Worker whose powers parallel those of the relative. Nearest relatives also have a right to be informed where the Approved Social Worker is seeking a compulsory admission. Where relatives object to a long-term admission for treatment, their objections can be overturned only by appeal to the County Court. Detailed accounts of the powers of the nearest relative are found in Hoggett and Beech (Hoggett, 1984; Beech, 1986).

The 1983 Act, section 26, defines closely who is to be identified as the "nearest relative"; establishing a hierarchy that starts with the spouse (unless permanently separated) and recognises co-habitees of six months' standing. Sons and daughters follow, regardless of sex, but giving preference to the one who is most involved in caring. The latter provision was added in the $1983 \mathrm{Act}$, and represents a slight shift away from a status-oriented, ascriptive definition towards one that reflects the particular patterns of caregiving. Parents follow; succeeded by siblings, grandparents, grandchildren, uncles and aunts, nieces and nephews, with priority given to the eldest and to whole blood over half blood. Finally the Act recognised the potential role of non-related care-givers, though the patient has to have been living with them for five years or more, and they can only be so recognised where no relative exists. Professionals have no discretion as to who is to be identified as the nearest relative, but someone so designated can authorise another to act.

The formal status accorded to relatives in mental health legislation is, as we have seen, unusual-at odds with their position elsewhere in the legal 
system, where their statutory rights are minimal, even non-existent, though the social reality of their involvement may be quite widely recognised. The situation has to be seen in the context of the longer history of mental health legislation, which is in turn rooted in an older discourse of madness and the family.

During the eighteenth century any relative or indeed friend who was willing to foot the bill could have someone committed to a private madhouse under the general common law ability to restrain a dangerous lunatic (Hoggett, 1984). During the early nineteenth century there was growing concern at the ability of relatives to have their kin put away in this fashion, and safeguards were instituted requiring that a doctor should support the application. The involvement of relatives was confined to those cases where the family took financial responsibility, and applied therefore only to the better-off. Pauper lunatics were brought before the justices who could direct that they be admitted to the County Asylum, and their families took no part in the matter.

The Lunacy Act 1890 brought these two streams together. After the optimism of the early nineteenth century, associated with the reforming moral management of madness, therapeutic pessimism set in. Asylums were increasingly seen as custodial institutions that required to be legally regulated. Much of the thrust of the 1890 Act was concerned to ensure that the sane did not unwittingly fall under regimes for the mad (Unsworth, 1987). The 1890 Act represented a shift from an earlier position where doctors were seen as important figures safeguarding patients against improper confinement by their relatives to one where relatives were seen as protection against unscrupulous asylum doctors. The 1890 Act laid down that the petition to have a person detained should wherever possible be presented by the husband, wife, or relative. If it were not, it should explain why not and state the connection between the lunatic and the petitioner. The petition, accompanied by a statement from two doctors, would then be presented to the magistrate. The petitioner was obliged to visit every six months or send a representative (Lunacy Act 1890).

The twentieth century saw a new, more medical emphasis on the treatment of the mad. Therapeutic optimism revived. The specialism of psychiatry developed and increasingly located itself within the same medical paradigm as physical illness (Unsworth, 1987). By the 1950s greater trust in the efficacy and goodwill of psychiatrists led to a desire to move away from the "legalism" of the 1890 Act that reformers regarded as inseparable from a punitive, scientifically uninformed view of mental disorder. The Mental Health Act 1959 ended judicial involvement in compulsory admissions in the form of a magistrate, replacing it by the decision of two doctors. Whereas under the 1890 Act medical judgement was not conclusive and was subject to lay authority, the 1959 Act abolished this and transferred the decision about confinement into the medical sphere. At the same time, however, the ability of relatives to seek compulsory admission and to apply for release was 
retained, transferred into the new statute broadly in the form that is current today.

At this time there was no systematic discussion as to why and whether relatives should remain involved in this way (Hoggett, 1984). The question of their privileged position was debated, however, in the run-up to the Mental Health (Amendment) Act 1982. This represented a swing back towards a more legally based approach, one emphasising the civil rights of the patient. Gostin among others argued that the actions of relatives were not always benign, and that they could be "an integral part of the patient's mental disorder" (Gostin, quoted in Hoggett, 1984).

The changes embodied in the 1983 Act represent as much the assertion of the new profession of social work as they do the control of doctors by civil rights principles. It was argued by those promoting the new professional perspective that it was inappropriate for relatives and social workers to have parallel powers. Social workers in making an application could provide a professionally-based social report on the case, whereas relatives could only speak from a personal perspective. The DHSS review of the proposed reforms noted these criticisms, but concluded that their powers should be retained. The report commented that some relatives "may prefer to feel that they are in control of the situation, and they will be in the best position to judge when they are unable to cope any longer with the patient" (DHSS, 1978, p. 32). The comment is significant in the context of our discussion of carers since it recognises that the involvement of relatives is not simply on the basis of their knowledge of and capacity to take decisions on behalf of their relatives but also on the basis of their own troubles or suffering. This as we shall see is nearer the understanding of the situation that is embodied in the term "carer."

\section{The rise of the term "carer"}

The word "carer" emerged in the 1970s in the context of an academic literature discussing community care. Popularised by pressure group politics and debates within academic feminism, it spread to professional and policymaking circles in the 1980s (Pahl, 1992; Twigg and Atkin, 1994). Though still a professionally-oriented term, it has achieved some currency in ordinary language and is now widely used by politicians and journalists. Care-giving relations had, of course, existed long before the development of the term. Its emergence, however, marked a new consciousness of the public policy issues raised by caring to which a number of factors contributed: demographic concern over the rising proportion of older people in the population; the active promotion of community care by Conservative governments who saw it as not only the preferred but also the cheaper option; countervailing anxieties among feminists and others as to the likely consequences of such policies on the lives of women, regarded (particularly in the early 1980s) as the main providers of informal care; and increased public awareness from 
research and from pressure groups like the Carers National Association of the burdens borne by many carers (Twigg and Atkin, 1994).

In the 1970s concern over the issue resulted in the development of a benefit for carers: Invalid Care Allowance. Provided for those who were out of work by virtue of caring, but initially excluding married women, its coverage has been limited by virtue of its interaction with other benefits and its exclusion of those over pensionable age (DHSS, 1974; McLaughlin, 1991). The Social Security Benefits Act 1975, cl. 37, does not use the word "carer", but refers to those who are "regularly and substantially engaged in caring" for "a severely disabled person" defined as someone in receipt of Attendance Allowance.

As we have seen, the NHS and Community Care Act 1990 and associated guidance left the word "carer" undefined. There was no attempt made to determine a hierarchy of responsibility as had existed in the liable relatives tradition or in mental health legislation, though as Qureshi and Walker have demonstrated, caring responsibilities do devolve on individuals in ways that reflect very similar hierarchies. The early literature on carers, starting as it did from concern over the support of older people and the differential burdens borne by daughters and daughters-in-law, tended to conceptualise caring in intergenerational terms. This does indeed represent the largest proportion of those offering care, but other relationships are also significant, notably those of spouses and of parents caring for children. Spouses are particularly significant in the support of middle-aged and younger elderly people, and their activities - particularly those of wives-are often obscured behind the mutual reciprocities of marriage (Parker, 1992b). Recognising that spouses could also be carers marked an important shift in the politics of the subject. Conceptualising parents as carers has, as we shall see, proved more controversial and the application of the term has in some degree been resisted by both parents and professionals. We shall return to this below.

So far we have seen caring in terms of kinship relations, but can friends and neighbours be carers? Certainly within the meaning of the Act they can since the term is not explicitly tied to family relations. In practice, however, they rarely take on this role. Friends and neighbours give valuable support to frail and disabled people, but what they do tends to be circumscribed, and they are not by and large involved in intensive or intimate care (Green, 1988; Sinclair, et al., 1990; Atkin, 1992). Above all the basis for their involvement is different, not rooted in kinship obligation but in more voluntaristic forms of association. The significance of this difference for public policy will be explored further below. Before doing so, however, we need to look at the elements that make up our understanding of being a "carer." I will outline these briefly and then suggest the particular significance of two of them in the emergence of the new terminology.

First, caring is most frequently understood as involving physical tasks of a supportive kind such as lifting, bathing, or feeding. It is not always easy to distinguish such caring tasks from the more general servicing work undertaken by women in families; and to this degree the care-giving work of men is 
often more easily defined and visible than that of women. The emphasis on the performance of tasks has been important in the conceptualisation of caring as work, often hard physical work. Second, caring is embedded in kinship. Nearly all caring takes place in the context of the family, governed by the norms of kinship obligation. Qureshi and Walker have suggested a hierarchy of caring responsibilities that descends through family relations, starting with spouses, followed by daughters, daughters-in-law and sons, though modified by factors such as geography or employment. Finch and Mason (1993) suggest that while such perceptions of hierarchy exist, they are subject to complex micro-negotiation. In both accounts, however, the concept of kinship obligation remains central. Third, caring is about emotion. Caring relationships are typically characterised by feelings of love, though not always in the straightforward way that the normative picture might suggest. Emotion is not only central to the experience of and motivation for care but also to the task; and caring can be conceptualised as a form of emotional labour.

The fourth element concerns the sense common to all carers that they are in some way responsible for the person they look after. Sometimes the responsibility turns around facilitating other forms of support; sometimes it means keeping an eye out for the person, stepping in when things go wrong or when help is needed. Lastly caring has to be recognised as something that has consequences for the carer's life. This is particularly so where the carer and the cared-for person share a household and where the impact of caring comes as much from the consequences of sharing your life with someone whose own life is limited or whose behaviour causes stress as from the tasks of caring itself.

\section{The significance of the term "carer"}

These last two elements-responsibility and consequences-are, I would argue, central to our understanding of the significance of the term "carer" and its recent emergence. "Carer" is never simply a word describing kinship relations. It has always carried a public policy component. It emerged within a discourse about community care and the responsibilities of the individual and the state. What was new and distinctive about the term was not so much that it delineated more clearly a particular family relationship previously obscured or overlooked, but that it implied a new moral claim within public discourse. This moral claim rests on a recognition that these are relations of obligation that can have severe consequences for carers and in which they are not free to abandon caring once the burdens have become onerous or the tasks distressing. Unlike friends and neighbours who are more peripherally involved and whose obligations are limited, they cannot withdraw at will. Carers are thus not free to act fully in their own interests and often continue to care against their own interests, as the extensive literature on the burdens borne by certain carers in the context of limited or no rewards makes plain (Wright, 1986; Lewis and Meredith, 1988; Ungerson, 1987; Levin, et al., 1989; Parker, 1990; Twigg, 1992). It is this fact that enables carers to lay claim to public consideration in their own right. Regarding someone as a carer 
rather than just a relative bestows on them a different status within public discourse. They have needs and interests that have to be recognised per se.

The extent to which these interests are in fact recognised is of course another matter. Welfare agencies have largely been content to ignore such claims, relying on the activities of carers but doing little to support or alleviate them. In so far as they have recognised the needs of carers, it has been on an instrumental basis, seeing support for carers as the most effective-often cost-effective-means of supporting older and disabled people.

I have explored elsewhere the tensions that arise for agencies in conceptualising their relationship with carers, distinguishing between a concept of the carer as a resource, as co-worker and as co-client (Twigg, 1989). These correspond in large measure to the difference between assuming the input of carers and excluding any consideration of their needs; adopting an instrumental approach to their support as a means of achieving other welfare ends; and a recognition of their needs and interests per se.

So long as the predominant conception remained that of regarding carers simply as a resource available in the community, the term carer was not needed; relative or family would suffice. Once public policy, however, had begun to encompass the second two elements, a new term was needed, and it was for that reason that the word "carer" emerged in public discourse in the 1980 s.

\section{The challenge to the concept of carer: the disability critique}

The conception of carers as people with an interest that requires public recognition has recently been subject to challenge. The disability movement has criticised what it sees as an improper emphasis on the needs of carers at the expense of those for whom they care (Oliver, 1990; Morris, 1991). In this view, rather than supporting carers in their activities, public policy should aim to enable disabled people to live independently and thus to transcend the need for caring relations. Focusing on the carer's needs and interests diverts attention from the real task in hand, and reinforces relations of subordination and dependence. Disabled people should be able to have and make relationships but these should not be made a basis for caring. The language of "carers" and "caring" should therefore be resisted and words such as "helper" substituted, words that separate practical assistance from any moral roots and place the disabled person clearly in control.

The social base of the disability movement is among younger people with physical disabilities and its theories reflect their experiences and aspirations. While I accept these ideas, certain provisos need to be made to their application. First, not all disabled people want to be free of reliance on their families. Some want and indeed demand that they be cared for. Spouses in particular often regard care as part of the mutual interdependence of marriage, and resist attempts to substitute for it. In these cases caring continues to have consequences for the carer and that fact deserves to be 
acknowledged. Second, there are situations where only the support of close relatives will enable a person to remain at home. This applies in particular to dementia where transcending the need for a carer is an unrealistic aspiration and one contrary to the interests of the disabled person.

The fact of kinship obligation and the strong affective bonds that it draws on means both that carers will continue to feel responsible for their relatives and that caring will have consequences for their lives. So long as this is the case, there is a need to incorporate their interest into public policy. The use of the word "carer" allows us to do so. This is not to argue that all care-giving relations are benign or that carers' interests should prevail over those of the cared-for person. What is required is a duality of focus: a recognition that care-giving takes place in a relationship in which both parties have legitimate interests which need to be balanced.

\section{The challenge to the concept of carer: other client groups}

The discourse on carers and caring emerged as part of the concern with the support of older people but its terminology has spread to other client groups. In two areas, however, it has met with some resistance: learning disabilities and mental health problems.

Parents of adults with learning disabilities are often reluctant to term themselves carers, preferring the word "parent" as better representing how they see the relationship. This is not dissimilar from the feelings of spouses and children looking after elderly parents who will also often deny that they are carers, preferring to see their activities in the context of the personal relationship. As we have noted, the word "carer" has retained some of the flavour of its original professional context. Where individuals do adopt it of themselves, it often marks a shift towards a more assertive attitude to the negotiation of public recognition and support (Twigg and Atkin, 1994). Sometimes service providers are instrumental in helping people make this shift into a self-perception as a carer. In the case of parents of adults with learning disabilities, service providers, particularly those of a progressivist stance, can be reluctant to be involved in this way. Encouraging parents to see themselves as carers implies their continuing responsibility for the person with learning disabilities. Theories of normalisation and independent living aim to allow the person with learning disability to leave home in the same way that non-disabled children do: to grow out of and beyond parental care and responsibility. To term parents "carers" denies that possibility. In progressive circles parents are increasingly perceived as at best overprotective and at worst substituting their interests for those of the person with learning disabilities (Hubert, 1990; Ward, 1990; McGrath, 1991). Implicitly recognising their interest through the use of the term "carer" has therefore been resisted, and the words "parent" or "relative" remain the predominant and preferred ones.

Similar tensions arise in relation to people with mental health problems, where the use of the word "carer" has made even less headway. This is partly 
because the field is medically dominated and doctors are less likely to conceptualise family relationships in terms of carers than are those with a social care perspective. The traditional focus of medicine is on the individual patient, even the individual condition; and doctors in so far as they consider the social context of the patient-and in most hospital consultations relatives and carers remain literally invisible-tend to conceptualise it in terms of "families" or "relatives," part of the background to the case but not part of the concern of the doctor. As a result the literature on families of people with mental health problems has developed in isolation from the main carer literature and is conceived in narrower terms (Perring et al., 1990). Families are primarily seen as a source of information about the patient; and their stresses and difficulties, where recognised, are largely so on an instrumental basis, something that may result in the collapse of care rather than something of concern per se (Twigg and Atkin, 1994).

Resistance to the term "carer" arises also for reasons that parallel those found in learning disabilities. The situations of people who develop schizophrenia in early adulthood are in many ways similar to those with learning disabilities, and professionals in this field have the same aspirations for their clients and patients to live independent lives. Parents are often perceived as overprotective and professionals are reluctant to encourage this through a perception of them as carers. In relation to problems such as depression, the status of relatives is more equivocal. The role of psychosocial factors in depression has long been recognised, indeed many would argue that such problems are best understood as arising from social circumstances with which the individual is unable to cope rather than from mental illness as such. Among these circumstances can be the family and marital relations of the sufferer. Relatives may thus be part of the problem-causers as well as carers-and professionals consequently reluctant to endorse their activities by recognising them as carers.

\section{The four legal traditions revisited}

The Poor Law defined the limits of legal obligation among family members in the context of the costs to the state of the upkeep of the destitute poor. As we have seen, it was part of a continuing debate around the question of who bears the responsibility for the support of older people in society, in which the emphasis has oscillated between the two poles of the state and the family. The current debate on carers is part of that tradition, though focused in a rather different way as the new terminology of carers makes plain. Unlike the old poor law debates, the issue is not primarily about financial support. The idea that people should have the basic financial means to live independently in old age is generally accepted. The debate around carers is about care rather than financial support, and turns around the provision of physical and emotional help to people who are disabled or frail. It is at that point that the terminology of the carer is triggered. 
In a second sense, too, the debate on carers is focused in a different way, in that the references to carers in the new legislation and guidance are not about enforcing obligation-overtly at least-but about acknowledging activities and burdens. It is about recognising care-giving rather than family responsibilities though the two are of course linked. It thus follows a social reality rather than attempting to impose one, recognising responsibilities that have been accepted and acted upon rather than making assumptions of responsibility based solely on the ascriptive criteria of family relationship.

Having said this, it may still be the case that the emergence of the term "carer" does have an enforcing quality to it, not so much in relation to the individual, as more generally within the policy debate. That which is named and defined in the discourse becomes actual-available, at least at the level of theory. It can be no coincidence that the term "carer" emerged just at the point when appreciation of the growing proportion of older people in the population resulted in heightened anxiety as to the costs of their care. Across Europe we can observe caring emerging as an issue in parallel with rising demographic and fiscal concern over old age. The language of caring and carers allows for the co-option of a new element in the care equation, for the slotting-in of a fourth sector-informal-to join those of public, voluntary and private in the new mixed economy of care.

In relation to inheritance, the rise of the term "carer" has had no direct impact in law. As we saw, however, changes in perception in the 1980 s meant that caring and inheritance were increasingly linked in the policy debate. How far are such links made by the families themselves? Has the concept of the care bargain revived in the wake of growing public familiarity with the issue of caring? Despite the enthusiasm of policy-makers, there is no empirical evidence to support the view that families are operating on such a basis. Finch and her colleagues in their study of inheritance and family obligation found no evidence of families entering into either explicit or implicit bargains whereby inheritance was adjusted to reflect care-giving (Finch and Wallis, 1992). Other principles such as the obligation to treat offspring equally were more determining. Finch and her colleagues remain sceptical of the existence of care bargains. Testamentary acts reflect the summation of a lifetime's relationships rather than the contingencies of current circumstances, and their roots lie in general moral obligations concerning kinship rather than in instrumental rewards for care-giving.

As we have seen, the legal role of relatives in decision-making is currently narrowly circumscribed. The shift towards care, however, has created a growing appreciation of their importance in the support of frail and disabled people-an importance reflected in the Law Commission Report. One focus of its concern has been with medical decision-making and the need to find a legal mechanism to enable surrogate decisions. Here relatives are incorporated in the proposals less as "carers" than as family members-individuals who are close to the patient and can be assumed to reflect the patient's likely views and interests. There is some recognition of the conceptual shift involved in the term "carer" in relation to other forms of decision-making, 
particularly those relating to daily living, with the recognition that individuals may need to be empowered to act as carers - to take decisions and have access to resources. The special position of the carer is acknowledged, but in a way that retains an instrumental focus: enabling the carer better to assist the disabled person. But adopting a carer focus also involves recognising that carers have needs per se. The nature of the relationship means that their interests are affected in parallel with those of the person they care for, and this could be said to endow them with a legitimate interest in relation to certain decisions. This aspect has not as yet been reflected in the current legal debate.

Mental health legislation is the one field where relatives' right to be involved in decision-making has been encoded. This is largely on the basis of their knowledge of the case, recognising that they are in a unique position to interpret the patient's current state and to be alert to deterioration. The current legislative position does contain a muted recognition that relatives can also be carers in the sense that they may take responsibility for the person with mental health problems and may suffer as a result of the care they give. But as we have seen, professionals are uneasy with such characterisations and unlikely to want to see any extension of the perception of relatives as carers.

\section{Conclusion}

The 1990 Act has brought carers out of the shadows of policy debate into the limelight of public statute. For the first time the interests of carers have been publicly recognised in law. It is as yet a limited recognition, confined to consultation, but one that through the associated guidance is achieving a wider remit. Though the law has touched on issues of family relations and responsibilities before, and thus tangentially on caring, it has done so within different conceptual frameworks, ones that have not focused on the particular nature of care-giving and the obligations and consequences associated with it. The emergence of the word "carer" and its use in statute mark a new departure for public policy, one in which caring is acknowledged as a public policy issue and in which the needs and interests of carers are recognised, albeit still within a predominantly instrumental framework.

\section{References}

Sara Arber, Nigel Gilbert and Maria Evandrou, "Gender, household composition and receipt of domiciliary services by the elderly disabled" (1988) Journal of Social Policy 17, 2: 153-175.

Karl Atkin, "Similarities and differences between informal carers" in J. Twigg (ed.), Carers: Research and Practice (1992) London: HMSO.

D. Beech, Social Work and Mental Disorder: A Practical Guide for Social Workers (1986) Birmingham: Pepar. 
M. A. Crowther, "Family responsibility and state responsibility in Britain before the welfare state" (1982) Historical Journal 25, 1: 131-145.

DHSS, Social Security Provision for Chronically Sick and Disabled People (1974) HC 276, London: HMSO.

DHSS, Review of the Mental Health Act 1959: Presented to Parliament by the Secretary of State for Social Services, the Secretary of State for the Home Department, the Secretary of State for Wales and the Lord Chancellor (1978) London: HMSO.

H. Dyson, "Wills and succession in France” (1987) Solicitor's Journal 131, 16: 493-496.

John Eekelaar, Family Law and Social Policy (1984) London: Weidenfeld \& Nicolson.

J. Finch, Family Obligations and Social Change (1989) Cambridge: Polity Press.

J. Finch and D. Groves (eds.), A Labour of Love: Women, Work and Caring (1983) London: Routledge.

J. Finch and J. Mason, Negotiating Family Responsibilities (1993) London: Routledge.

J. Finch and L. Wallis, "Inheritance, care bargains and elderly people's relationships with their children" (1992) paper presented to British Gerontological Society Annual Conference, University of Kent, Canterbury.

H. Green, Informal Carers: A Study Carried out on Behalf of the Department of Health and Social Security as Part of the 1985 GHS (1988) London: HMSO.

M. J. Gunn, "Treatment and mental handicap" (1987) Anglo-American Law Review 16, 3: 242-267.

B. Hoggett, Mental Health Law (1984) London: Sweet \& Maxwell.

B. M. Hoggett and D. S. Pearl, The Family, Law and Society: Cases and Materials (1991) London: Butterworth.

J. Hubert, "At home and alone: Families and young adults with challenging behaviour" in T. Booth (ed.) Better Lives: Changing Services For People with Learning Difficulties (1990) Sheffield: Joint unit for Social Services Research/ Community Care.

A. M. Hudson and R. Barbalich, "Succession law in France and Italy" (20 September, 1991) Solicitor's Journal 135, 1032-1033.

Ian Kennedy, The Unmasking of Medicine (1981) London: Allen \& Unwin.

Ian Kennedy, Treat Me Right: Essays in Medical Law and Ethics (1988) Oxford: Clarendon Press. 
P. Laslett with R. Wall, Household and Family in Past Times (1972) Cambridge: Cambridge University Press.

P. Laslett, Family Life and Illicit Love in Earlier Generations: Essays in Historical Sociology (1977) Cambridge: Cambridge University Press.

Law Commission, Mentally Incapacitated Adults and Decision-Making: An Overview (1991) Consultation Paper 119, London: Law Commission.

Law Society, Decision-Making and Mental Incapacity: A Discussion Document (1989) London: Law Society.

E. Levin, I. Sinclair and P. Gorbach, Families, Services and Confusion in Old Age (1989) Aldershot: Gower.

J. Lewis and B. Meredith, Daughters Who Care: Daughters Caring for Mothers at Home (1988) London: Routledge.

M. McGrath, Multi-disiplinary Teamwork: Community Mental Handicap Teams (1991) Aldershot: Avebury

E. McLaughlin, Social Security and Community Care: The Case of the Invalid Care Allowance (1991) London: HMSO.

Jenny Morris, Pride Against Prejudice: Transforming Attitudes to Disability (1991) London: Women's Press.

C. Oldman, Paying for Care: Personal Sources of Funding Care (1991) York: Joseph Rowntree Foundation.

Mike Oliver, The Politics of Disablement (1990) London: Macmillan.

R. D. Oughton and E. L. G. Tyler, Tyler's Family Provision (1984) Abingdon: Professional Books.

J. Pahl, "The impact of feminist research on community care policy" in R. Smith and L. Harrison (eds.), Community Care Research and Community Care Policy (1992) Bristol: School for Advanced Urban Studies.

G. Parker, With Due Care and Attention: A Review of Research on Informal Care (1990) London: Family Policy Studies Centre.

G. Parker, "Counting care: numbers and types of informal carers" in J. Twigg (ed.), Carers: Research and Practice (1992a) London: HMSO.

G. Parker, With This Body: Caring and Disability in Marriage (1992b) Buckingham: Open University Press.

C. Perring, J. Twigg and K. Atkin, Families Caring for a Person Diagnosed as Mentally Ill: The Literature Re-examined (1990) London: HMSO.

H. Qureshi and A. Walker, The Caring Relationship: Elderly People and Their Families (1989) Basingstoke: Macmillan. 
M. Rheinstein, "Duty of children to support parents" in E. W. Burgess (ed.), Ageing in Western Societies (1960) Chicago: University of Chicago Press.

A. Scull, "The theory and practice of civil commitment" in A. Scull, Social Order/Mental Disorder: Anglo-American Psychiatry in Historical Perspective (1989) London: Routledge.

I. Sinclair, R. Parker, D. Leat and J. Williams, The Kaleidoscope of Care: $A$ Review of Welfare Provision for Elderly People (1990) London: HMSO.

R. M. Smith, "The structured dependence of the elderly as a recent development: some sceptical historical thoughts" (1984) Ageing and Society 4: 4 .

A. B. Sorenson. "Old age, retirement and inheritance" in D. I. Kenzer and W. Warner Schaie (eds.). Age Structuring in Comparative Perspective (1989) Hillsdale, NJ: Lawrence Erlbaum.

D. Thomson, "Welfare and the historians" in L. Bonfield, R. M. Smith and K. Wrightson (eds.). The World We Have Gained: Histories of Population and Social Structure (1986) Oxford: Blackwell.

D. Thomson. "The welfare of the elderly in the past: a family or community responsibility?" in R. M. Smith and M. Pelling (eds.), Life, Death and the Elderly: Historical Perspectives (1991) London: Routledge.

J. Twigg. "Models of carers: how do agencies conceptualise their relation with informal carers?" (1989) Journal of Social Policy 18, 1: 53-66.

J. Twigg (ed.), Carers: Research and Practice (1992) London: HMSO.

J. Twigg and K. Atkin, Carers Perceived: Policy and Practice in Informal Care (1994) Milton Keynes: Open University Press.

C. Ungerson. Policy is Personal: Sex. Gender and Informal Care (1987) London: Tavistock.

C. Unsworth. The Politics of Mental Health Legislation (1987) Oxford: Clarendon Press.

L. Ward. A programme for change: current issues in services for people with learning disabilities" in T. Booth (ed.) Better Lives: Changing Services for people with hearing Disabilities (1990) Sheffield: Joint Unit for Social Services Research / Community Care

F. D. Wright, Left to Care Alone (1986) Aldershot: Gower. 